Archived version from NCDOCKS Institutional Repository http://libres.uncg.edu/ir/asu/

\title{
Appalacȟnan
}

B O O NE, NORTH CAROLINA

\section{The Reading Level Of Government And Voluntary Health Organization Smoking Cessation Websites: A Descriptive Analysis}

\author{
By: Christopher M. Seitz, Samantha Shiplo, Taylor Filippini, Zubair Kabir, \\ Jeffrey L. Lennon, and Donald Fowler
}

\begin{abstract}
Background: The U.S. Department of Health \& Human Services (USDHHS) recommends that health material be written at or below a sixth-grade reading level to ensure readability. Purpose: The aim of this study was to investigate the readability of online smoking cessation materials from several government and voluntary health organizations. Methods: A purposive sample of publicly accessible governmental and voluntary health organization websites was selected. The readability of the websites' smoking cessation information was estimated using the previously validated SMOG readability formula, which determined reading level by correlating the number of polysyllabic words. Results: Of the 55 websites included in the analysis, none had cessation information at the USDHHS's recommended reading level. The material ranged in reading level from seventh grade to a third year in college. Discussion: The findings indicate that the online cessation materials need to be modified in order to reach recommended reading levels. Translation to Health Education Practice: This study can be of practical use to Health Educators when designing, modifying, and evaluating smoking cessation materials. Several free, online government resources are available to assist Health Educators in using simple, non-polysyllable words to ensure that smoking cessation materials are written at the recommended reading levels.
\end{abstract}

Christopher M. Seitz, Samantha Shiplo, Taylor Filippini, Zubair Kabir, Jeffrey L. Lennon \& Donald Fowler (2017). The Reading Level of Government and Voluntary Health Organization Smoking Cessation Websites: A Descriptive Analysis, American Journal of Health Education, 48:6, 392-399, DOI: 10.1080/19325037.2017.1358122. Publisher version of record available at: http:// dx.doi.org/10.1080/19325037.2017.1358122 


\title{
The Reading Level of Government and Voluntary Health Organization Smoking Cessation Websites: A Descriptive Analysis
}

\author{
Christopher M. Seitz ${ }^{\mathrm{a}}$, Samantha Shiplo ${ }^{\mathrm{b}}$, Taylor Filippinic ${ }^{\mathrm{c}}$, Zubair Kabir ${ }^{\mathrm{b}}$, Jeffrey L. Lennon ${ }^{\mathrm{d}}$, and Donald Fowler ${ }^{\mathrm{d}}$

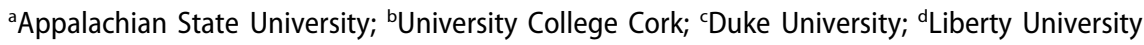

\begin{abstract}
Background: The U.S. Department of Health \& Human Services (USDHHS) recommends that health material be written at or below a sixth-grade reading level to ensure readability. Purpose: The aim of this study was to investigate the readability of online smoking cessation materials from several government and voluntary health organizations. Methods: A purposive sample of publicly accessible governmental and voluntary health organization websites was selected. The readability of the websites' smoking cessation information was estimated using the previously validated SMOG readability formula, which determined reading level by correlating the number of polysyllabic words. Results: Of the 55 websites included in the analysis, none had cessation information at the USDHHS's recommended reading level. The material ranged in reading level from seventh grade to a third year in college. Discussion: The findings indicate that the online cessation materials need to be modified in order to reach recommended reading levels. Translation to Health Education Practice: This study can be of practical use to Health Educators when designing, modifying, and evaluating smoking cessation materials. Several free, online government resources are available to assist Health Educators in using simple, non-polysyllable words to ensure that smoking cessation materials are written at the recommended reading levels.
\end{abstract}

\section{Background}

Smoking is a major public health issue in the United States. Roughly $15 \%$ of adults in the United States, over 36 million people, are current smokers. ${ }^{1}$ It is estimated that every day, over 3200 people under 18 years old smoke for the first time. ${ }^{2}$ In addition, each day, roughly 2100 adolescents and young adults will transition from occasional smokers to daily smokers. ${ }^{2}$

Firsthand and secondhand smoke is associated with negative health outcomes. Over 16 million Americans are currently coping with a disease caused by smoking. Decades of research show sufficient evidence to infer a causal relationship between smoking and several cancers and diseases. For example, research strongly indicates that smoking causes lung cancer, liver cancer, colorectal cancer, prostate cancer, and breast cancer. ${ }^{2}$ Likewise, research suggests that smoking causes chronic obstructive pulmonary disease, emphysema, chronic bronchitis, heart disease, stroke, diabetes, early pregnancy, ectopic pregnancy, and erectile dysfunction. ${ }^{2}$

In addition, firsthand and secondhand smoke is associated with mortality. In fact, smoking is the still the leading cause of preventable death in the United States. Researchers estimate that smoking kills $480 \quad 000$
Americans each year, including 41000 deaths from secondhand smoke. ${ }^{2}$ In other words, smoking causes roughly one out of every 5 deaths in the United States, or 1300 deaths per day. ${ }^{2}$

The Centers for Disease Control and Prevention recommend that public health professionals promote the use of smoking cessation websites as part of the overall strategy to help people quit smoking. ${ }^{3,4}$ In 2004 , a national randomized telephone survey found that 95 million adults used the Internet to find health information, of whom 7\% (over 6 million people) searched how to quit smoking. ${ }^{5}$ In 2012, a nationwide, federally funded mass media smoking cessation campaign resulted in 629898 unique visitors to the campaign's cessation website, a $428 \%$ increase from the same period the prior year. ${ }^{3}$ Evidence suggests that smoking cessation websites can be effective in helping smokers make quit attempts ${ }^{6-9}$ and learn how to cope from withdrawal. ${ }^{10}$

Overall, the literacy level of adults in the United States is low, especially among those who smoke. The U.S. Department of Education's National Assessment of Adult Literacy found that $14 \%$ of adults (30 million people) have only a "below basic" literacy level and 29\% (63 million) have a "basic" literacy level. ${ }^{11}$ It is well established that

CONTACT Christopher M. Seitz seitzcm@appstate.edu Department of Health \& Exercise Science, Appalachian State University, 111 Rivers Street, PO Box 32071, Boone, NC 28608-2026. 
smoking is more common among those with lower levels of education, ${ }^{1}$ suggesting that smokers are less "health literate" when compared to the general population. For example, in a study involving 258 smokers from a local hospital, $54 \%$ of the patient sample had a reading level of less than the sixth grade. ${ }^{12}$ Another study showed that $18 \%$ of the 599 pregnant smokers sampled from an obstetrics clinic had a reading level at or below the sixth grade. ${ }^{13}$

As such, the U.S. Department of Health \& Human Services (USDHHS) recommends that written health material should be clear and effective. Specifically, the USDHHS regards material written at or below a sixthgrade reading level as "easy" to read, material between seventh grade to ninth grade is considered "average," and material written at or above the 10th-grade reading level is "difficult" to read. ${ }^{14}$ The USDHHS generally recommends that health materials be written at or below a sixth-grade reading level, especially for materials that health educators would like to be easy to read, ${ }^{14}$ such as smoking cessation materials. This recommendation was also made in Doak et al's ${ }^{15}$ well-cited book and in the American Medical Association's guide ${ }^{16}$ on how to communicate with patients who have low levels of literacy. Since then, several research studies have used the recommended reading level as a rule of thumb for investigating the reading level of materials on a wide range of medical topics, such as heart disease, cancer, stroke, chronic obstructive pulmonary disease, skin disease, surgery, and so on. ${ }^{17,18}$

There are few studies on the readability of online smoking cessation materials. Several previous studies have reported that smoking cessation materials in print form have been written at a high reading level ${ }^{12,19-22}$; however, only a few studies have focused on online smoking cessation materials. In 2003, Cheh et $\mathrm{al}^{23}$ assessed the quality and usability of 30 popular smoking cessation websites, which were selected from smoking cessation books that recommended certain websites, as well as from a general Internet search engine. Of the websites included in the study, one was from the Centers for Disease Control and Prevention, 3 were from state health departments, and one was from the American Lung Association. Other websites were from private companies, nonprofit organizations, and websites from other countries, including Canada, Australia, and the United Kingdom. In their analysis, Cheh et al found that only $2(6.7 \%)$ websites were written at below the sixth-grade level. ${ }^{23}$

Likewise, Bock and colleagues ${ }^{24}$ studied the quality and usability of 46 smoking cessation websites. The websites were screened and selected from several Internet search engines. The websites included one from the Centers for Disease Control and Prevention, one from the Surgeon General, one from a state health department, and one from the American Cancer Society. Other websites were from private companies, nonprofit organizations, and websites from other countries, including Canada and the United Kingdom. The websites had an average reading level of eighth grade and $25 \%$ of the websites were written at or above the 12th-grade level. ${ }^{24}$

Finally, Brunette and colleagues ${ }^{25}$ examined the adequacy of content and usability of the homepage and medication page of 4 smoking cessation websites. The first 4 websites were selected using an Internet search engine, which included 2 from private foundations, one from a tobacco company, and one from the U.S. Department of Health and Human Services. Brunette et al found that only 2 of the 4 websites' homepages and only one medication page were below the sixth-grade reading level. ${ }^{25}$

\section{Purpose}

Taken together, it is important that we ascertain the readability of online smoking cessation materials promoted by leading government health agencies and highly recognized voluntary health organizations. As mentioned previously,

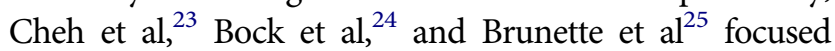
primarily on .com websites from tobacco industries, private companies, nonprofit organizations, and health organizations from other countries. These studies did not explicitly focus on smoking cessation websites from leading health organizations that value and promote evidence-based practices, such as making health material readable by those with low literacy skills. As such, our study builds upon the work of previous studies by determine the reading level of online smoking cessation materials from several federal, state, and esteemed voluntary health organizations' websites.

\section{Methods}

\section{Website selection}

In April 2016, the cessation websites analyzed in this study were gathered as a purposive sample of leading governmental and voluntary health organizations. These included websites from several federal government health agencies, state health departments, and several voluntary health organizations with an emphasis on smoking cessation. Specifically, each state health department's smoking cessation website was included in the study. In terms of federal and voluntary agencies, websites were selected as a purposive, convenience sample based upon the researchers' knowledge and experience regarding recognized smoking cessation websites.

The websites were included in the study if they contained smoking cessation information for smokers. The websites were excluded if they (1) did not include smoking cessation information for smokers, (2) only 
listed a phone number to the state quitline, or (3) had malfunctioning hyperlinks.

\section{Data analysis}

The smoking cessation information from each website was analyzed using the $\mathrm{SMOG}^{26}$ (Simple Measure of Gobbledygook) ${ }^{27}$ readability formula. McLaughlin created SMOG to estimate the readability of material based upon the total number of polysyllabic words, which are words made up of 3 or more syllables. ${ }^{26}$ The SMOG readability is considered accurate and is highly correlated with other readability formulas; as such, SMOG has been recommended by the U.S. National Cancer Institute for determining the reading level of informational pamphlets about cancer. ${ }^{28}$ Moreover, SMOG is one of the readability formulas recommended by the USDHHS and is commonly used by researchers and practitioners in medical and public health fields. ${ }^{29}$

Before using the SMOG formula, a sample of sentences was collected from the entire text. In the procedure, 10 consecutive sentences were collected near the beginning of the text, as well as near the middle and end of the text, for a total sample of 30 sentences. ${ }^{26}$ The SMOG formula defines a sentence as several words that are punctuated with a period, question mark, or exclamation point. In addition, words that are assessed for being polysyllabic include hyphenated words (which are considered a single word), numbers (pronounced to assess whether they are polysyllabic), proper nouns, and abbreviations (which are read as unabbreviated). ${ }^{14,29,30}$ For this study, the entirety of each website's smoking cessation information was copied and pasted into its own respective document. The sample of sentences was gathered near the beginning, middle, and end of the document.

It is important to note that text not targeted toward smokers was not included in the sample of sentences. Because our study is focused the readability of smoking cessation websites that are written for smokers, we did not want to include information on websites that were written for nonsmokers. For example, several websites had portions of text dedicated to educating the family members or friends of a smoker how to encourage the smoker to make a quit attempt. Because this information was not specifically written for a smoker to read, it was not included when sampling sentences.

From the sample of 30 sentences, the SMOG formula was used to determine the reading level. All of the polysyllabic words in the sample were tallied by highlighting and counting the words, including any polysyllabic words that were repeated. The square root of the total number of polysyllabic words was then estimated by taking the square root of the nearest perfect square. As an example, if there were 95 polysyllable words within the 30 -sentence sample, its nearest perfect square would be 100 , giving a square root of 10. If, however, the total number of polysyllable words fell between 2 perfect squares, the lower number was chosen for the formula. For example, if there were a total of 110 polysyllable words within the 30 -sentence sample, the lower square root of 100 would be used for the SMOG formula, instead of 121. Finally, a constant of 3 was added to the square root, resulting in the SMOG grade, which is the reading grade level. In the previous example, the reading level would be 13, which would be considered the first year of college. It should be noted that due to the standard error of the SMOG formula, the reading level is estimated within \pm 1.5 reading levels. ${ }^{26}$

There was a modified procedure for text that does not contain a total of 30 sentences. First, the total number of sentences was counted. Then, all of the polysyllabic words were tallied and the average number of polysyllabic words was calculated per sentence. Next, the total number of sentences was subtracted from 30 and then multiplied by the average. That number was then added to the total number of polysyllabic words. Finally, the nearest perfect square root was determined and added to the constant of $3 .{ }^{29}$

Finally, the authors omitted polysyllabic words that would be commonly known. These words included polysyllabic states (eg, Alabama, Minnesota, Tennessee), because the smoker would likely be able to read and recognize the name of the state in which they reside. In addition, the authors omitted polysyllabic words that would be common among smokers: tobacco, nicotine, and cigarette(s).

\section{Results}

A total of 59 websites were selected, including 5 websites from national health organizations (Table 1), 50 state health organizations (Table 2), and 4 voluntary health

Table 1. Reading level of federal health organization smoking cessation websites. ${ }^{\text {a }}$

\begin{tabular}{llc}
\hline Health organization & \multicolumn{1}{c}{ Website } & $\begin{array}{c}\text { Reading } \\
\text { level }\end{array}$ \\
\hline USDHHS, NIH, NCl & http://smokefree.gov/ & 8 \\
USDHHS & http://betobaccofree.hhs.gov/ & 9 \\
$\begin{array}{l}\text { U.S. Department of } \\
\text { Defense }\end{array}$ & 7 \\
FDA & https://www.ucanquit2.org/ & 7 www.fda.gov/ForConsumers/ \\
NCl & $\begin{array}{l}\text { ConsumerUpdates/ucm198176.htm } \\
\text { http://www.cancer.gov/about-cancer/ } \\
\text { causes-prevention/risk/tobacco/quit- } \\
\text { smoking-pdq\#section/all }\end{array}$ & 15 \\
\hline
\end{tabular}

aUSDHS indicates U.S. Department of Health and Human Services; NIH National Institutes of Health; NCl, National Cancer Institute; FDA, U.S. Food and Drug Administration. 
Table 2. Reading level of state health organization smoking cessation websites. ${ }^{a}$

\begin{tabular}{|c|c|c|}
\hline Health organization & Website & $\begin{array}{l}\text { Reading } \\
\text { level }\end{array}$ \\
\hline $\begin{array}{l}\text { Alabama Department of } \\
\text { Health }\end{array}$ & https://alabama.quitlogix.org/ & 11 \\
\hline $\begin{array}{l}\text { Alaska Department of Health } \\
\text { and Human Services }\end{array}$ & $\begin{array}{l}\text { https://www.quitnow.net/ } \\
\text { alaska/ }\end{array}$ & 9 \\
\hline $\begin{array}{l}\text { Arizona Department of } \\
\text { Health Services }\end{array}$ & http://ashline.org/ & 9 \\
\hline $\begin{array}{l}\text { Arkansas Department of } \\
\text { Health }\end{array}$ & $\begin{array}{l}\text { http://www.stampoutsmoking. } \\
\text { com/ }\end{array}$ & 11 \\
\hline $\begin{array}{l}\text { The California Department of } \\
\text { Public Health }\end{array}$ & $\begin{array}{l}\text { http://www.nobutts.org/ } \\
\text { tobacco-users-welcome }\end{array}$ & 7 \\
\hline $\begin{array}{l}\text { Colorado Department of } \\
\text { Public Health \& } \\
\text { Environment }\end{array}$ & https://www.coquitline.org/ & 11 \\
\hline $\begin{array}{l}\text { Connecticut Department of } \\
\text { Public Health }\end{array}$ & $\begin{array}{l}\text { https://www.quitnow.net/ } \\
\text { connecticut/ }\end{array}$ & 9 \\
\hline $\begin{array}{l}\text { Delaware Department of } \\
\text { Health and Social Services }\end{array}$ & $\begin{array}{l}\text { https://www.quitnow.net/ } \\
\text { Delaware/ }\end{array}$ & 9 \\
\hline Florida Department of Health & $\begin{array}{l}\text { http://www.tobaccofreeflorida. } \\
\text { com/ }\end{array}$ & 10 \\
\hline $\begin{array}{l}\text { Georgia Department of } \\
\text { Public Health }\end{array}$ & $\begin{array}{l}\text { https://dph.georgia.gov/ready- } \\
\text { quit }\end{array}$ & 11 \\
\hline $\begin{array}{l}\text { State of Hawaii, Department } \\
\text { of Health }\end{array}$ & http://hawaiiquitline.org/ & 11 \\
\hline $\begin{array}{l}\text { Idaho Department of Health } \\
\text { and Welfare }\end{array}$ & http://projectfilter.org/ & 12 \\
\hline $\begin{array}{l}\text { Illinois Department of Public } \\
\text { Health }\end{array}$ & http://quityes.org/index.html & 10 \\
\hline $\begin{array}{l}\text { Indiana State Department of } \\
\text { Health }\end{array}$ & $\begin{array}{l}\text { http://www.quitnowindiana. } \\
\text { com/index.html }\end{array}$ & 11 \\
\hline $\begin{array}{l}\text { lowa Department of Public } \\
\text { Health }\end{array}$ & $\begin{array}{l}\text { https://www.quitnow.net/ } \\
\text { iowa/ }\end{array}$ & 9 \\
\hline $\begin{array}{l}\text { Kansas Department of Health } \\
\text { \& Environment }\end{array}$ & http://www.ksquit.org/ & 9 \\
\hline $\begin{array}{l}\text { Kentucky Department for } \\
\text { Public Health }\end{array}$ & $\begin{array}{l}\text { https://www.quitnowken } \\
\text { tucky.org/default.aspx }\end{array}$ & 11 \\
\hline $\begin{array}{l}\text { Louisiana Department of } \\
\text { Health \& Hospitals }\end{array}$ & http://www.quitwithusla.org/ & 10 \\
\hline $\begin{array}{l}\text { Maine Department of Health } \\
\text { and Human Services }\end{array}$ & $\begin{array}{l}\text { http://www.tobaccofreemaine. } \\
\text { org/ }\end{array}$ & 12 \\
\hline $\begin{array}{l}\text { Maryland Department of } \\
\text { Health and Mental } \\
\text { Hygiene }\end{array}$ & http://smokingstopshere.com/ & 9 \\
\hline $\begin{array}{l}\text { Massachusetts Department } \\
\text { of Public Health }\end{array}$ & $\begin{array}{l}\text { http://makesmokinghistory. } \\
\text { org/ }\end{array}$ & 8 \\
\hline $\begin{array}{l}\text { Michigan Department of } \\
\text { Health \& Human Services }\end{array}$ & https://michigan.quitlogix.org/ & 11 \\
\hline $\begin{array}{l}\text { Minnesota Department of } \\
\text { Health }\end{array}$ & https://www.quitplan.com/ & 8 \\
\hline $\begin{array}{l}\text { Mississippi State Department } \\
\text { of Health }\end{array}$ & $\begin{array}{l}\text { http://www.quitlinems.com/ } \\
\text { index.php }\end{array}$ & 9 \\
\hline $\begin{array}{l}\text { Missouri Department of } \\
\text { Health \& Senior Services }\end{array}$ & $\begin{array}{l}\text { https://www.quitnow.net/ } \\
\text { missouri/ }\end{array}$ & 9 \\
\hline $\begin{array}{l}\text { Montana Department of } \\
\text { Public Health and Human } \\
\text { Services }\end{array}$ & https://montana.quitlogix.org/ & 11 \\
\hline $\begin{array}{l}\text { Nebraska Department of } \\
\text { Health and Human } \\
\text { Services }\end{array}$ & $\begin{array}{l}\text { https://www.quitnow.net/ } \\
\text { nebraska/ }\end{array}$ & 9 \\
\hline $\begin{array}{l}\text { Nevada Department of } \\
\text { Health and Human } \\
\text { Services }\end{array}$ & https://nevada.quitlogix.org/ & 11 \\
\hline $\begin{array}{l}\text { New Hampshire Department } \\
\text { of Health and Human } \\
\text { Services }\end{array}$ & http://trytostopnh.org/ & 10 \\
\hline $\begin{array}{l}\text { State of New Jersey } \\
\text { Department of Health }\end{array}$ & http://www.njquitline.org/ & 8 \\
\hline $\begin{array}{l}\text { New Mexico Department of } \\
\text { Health }\end{array}$ & http://quitnownm.com/ & NA \\
\hline $\begin{array}{l}\text { New York State Department } \\
\text { of Health }\end{array}$ & http://www.nysmokefree.com/ & 9 \\
\hline
\end{tabular}

(Continued)
Table 2. (Continued).

\begin{tabular}{|c|c|c|}
\hline Health organization & Website & $\begin{array}{l}\text { Reading } \\
\text { level }\end{array}$ \\
\hline $\begin{array}{l}\text { North Carolina Department } \\
\text { of Health and Human } \\
\text { Services }\end{array}$ & http://www.quitlinenc.com/ & 9 \\
\hline $\begin{array}{l}\text { North Dakota Department of } \\
\text { Health }\end{array}$ & $\begin{array}{l}\text { https://quitnet.meyouhealth. } \\
\text { com/\#/ }\end{array}$ & NA \\
\hline Ohio Department of Health & https://ohio.quitlogix.org/ & 11 \\
\hline $\begin{array}{l}\text { Oklahoma State Department } \\
\text { of Health }\end{array}$ & http://www.okhelpline.com/ & 8 \\
\hline $\begin{array}{l}\text { Oregon Public Health } \\
\text { Division }\end{array}$ & $\begin{array}{l}\text { https://www.quitnow.net/ } \\
\text { oregon/ }\end{array}$ & 9 \\
\hline $\begin{array}{l}\text { Pennsylvania Department of } \\
\text { Health }\end{array}$ & https://pa.quitlogix.org/ & 11 \\
\hline $\begin{array}{l}\text { State of Rhode Island } \\
\text { Department of Health }\end{array}$ & http://quitnowri.com/ & NA \\
\hline $\begin{array}{l}\text { South Carolina Department } \\
\text { of Health \& Environmental } \\
\text { Control }\end{array}$ & $\begin{array}{l}\text { https://www.quitnow.net/ } \\
\text { southcarolina/ }\end{array}$ & 9 \\
\hline $\begin{array}{l}\text { South Dakota Department of } \\
\text { Health }\end{array}$ & http://sdquitline.com/ & 10 \\
\hline $\begin{array}{l}\text { Tennessee Department of } \\
\text { Health }\end{array}$ & http://www.tnquitline.org/ & 8 \\
\hline $\begin{array}{l}\text { Texas Department of State } \\
\text { Health Services }\end{array}$ & http://www.yesquit.org/ & 9 \\
\hline Utah Department of Health & http://waytoquit.org/ & 8 \\
\hline $\begin{array}{l}\text { Vermont Department of } \\
\text { Health }\end{array}$ & http://802quits.org & 7 \\
\hline $\begin{array}{l}\text { Virginia Department of } \\
\text { Health }\end{array}$ & $\begin{array}{l}\text { https://www.quitnow.net/ } \\
\text { virginia/ }\end{array}$ & 9 \\
\hline $\begin{array}{l}\text { Washington State } \\
\text { Department of Health }\end{array}$ & $\begin{array}{l}\text { http://www.doh.wa.gov/ } \\
\text { YouandYourFamily/Tobacco/ } \\
\text { HowtoQuit }\end{array}$ & NA \\
\hline $\begin{array}{l}\text { West Virginia Department of } \\
\text { Health and Human } \\
\text { Resources }\end{array}$ & $\begin{array}{l}\text { http://www.bebetter.net/ } \\
\text { wvquitline_home.html }\end{array}$ & 10 \\
\hline $\begin{array}{l}\text { Wisconsin Department of } \\
\text { Health Services }\end{array}$ & $\begin{array}{l}\text { http://www.ctri.wisc.edu/smo } \\
\text { kers.htm }\end{array}$ & 9 \\
\hline $\begin{array}{l}\text { Wyoming Department of } \\
\text { Health }\end{array}$ & $\begin{array}{l}\text { https://wyo.quitlogix.org/ } \\
\text { default.aspx }\end{array}$ & 11 \\
\hline
\end{tabular}

Table 3. Reading level of voluntary health organization smoking cessation websites.

\begin{tabular}{|c|c|c|}
\hline $\begin{array}{l}\text { Health } \\
\text { organization }\end{array}$ & Website & $\begin{array}{l}\text { Reading } \\
\text { level }\end{array}$ \\
\hline $\begin{array}{l}\text { American Cancer } \\
\text { Society }\end{array}$ & $\begin{array}{l}\text { http://www.cancer.org/healthy/stayaway } \\
\text { fromtobacco/index }\end{array}$ & 10 \\
\hline American Heart & http://www.heart.org/HEARTORG/ & 11 \\
\hline Association & $\begin{array}{l}\text { GettingHealthy/QuitSmoking/Quit- } \\
\text { Smoking_UCM_001085_SubHomePage.jsp }\end{array}$ & \\
\hline $\begin{array}{l}\text { American Lung } \\
\text { Association }\end{array}$ & $\begin{array}{l}\text { http://www.lung.org/stop-smoking/i-want- } \\
\text { to-quit/ }\end{array}$ & 8 \\
\hline $\begin{array}{l}\text { World Health } \\
\text { Organization }\end{array}$ & $\begin{array}{l}\text { http://www.who.int/tobacco/publications/ } \\
\text { smoking_cessation/9789241506939/en/ }\end{array}$ & 12 \\
\hline
\end{tabular}

organizations (Table 3); however, 4 state departments of health were excluded from the analysis because the websites did not include smoking cessation information. These websites either only listed a phone number to the state quitline or had malfunctioning hyperlinks at the time of the study.

It is important to note that most state departments of health cessation websites were paired with their state quitline. In addition, several states utilized the websites quitlogix.org or quitnow.net as their state's smoking 
Table 4. Websites distributed by reading level and USDHHS classifications. $^{\text {a }}$

\begin{tabular}{lll}
\hline Reading level & USDHHS & No. websites (\%) \\
\hline Fourth grade & Easy & $0(0)$ \\
Fifth grade & & $0(0)$ \\
Sixth grade & $0(0)$ \\
Seventh grade & Average & $3(5)$ \\
Eighth grade & & $8(15)$ \\
NInth grade & $18(33)$ \\
10th grade & Difficult & $7(13)$ \\
11th grade & & $15(27)$ \\
12th grade & $3(5)$ \\
First year college & $0(0)$ \\
Second year college & $0(0)$ \\
Third year college & $1(2)$ \\
aUSDHHS indicates U.S. Department of Health and Human Services.
\end{tabular}

cessation website. The smoking cessation information provided by those state websites was identical, with the exception of the name of each state.

Of the 55 websites included in the analysis, reading levels ranged from seventh grade to third year in college. The median reading level was ninth grade $(\mathrm{M}=9.96, \mathrm{SD}=1.51)$. None of the websites were written at an easy reading level (ie, fourth grade to sixth grade) recommended by the USDHHS (Table 4). A Kruskal-Wallis $\mathrm{H}$ test was performed to determine whether there was a statistically significant difference in reading level of online smoking cessation materials between state, federal, and voluntary agencies; no significant difference was found, $\chi^{2}(2)=0.79, P=.67$.

\section{Discussion}

The purpose of this study was to assess the readability of online smoking cessation materials created by government health agencies and voluntary health organizations. The study built upon previous studies by Cheh et $\mathrm{al}^{23}$ Bock et $\mathrm{al}^{24}$ and Brunette et $\mathrm{al}^{25}$ by focusing on online smoking cessation materials from health organizations that claim to use evidence-based practices, rather than from other organizations, which may not be aware of evidence-based practices of Health Education, such as creating smoking cessation materials that are easy to read. Of the 55 websites analyzed in the study, none had a recommended reading level of fourth grade to sixth grade. It is important to reflect on these findings and discuss their implications for practice and future research.

The study's findings suggested that government and voluntary health organizations' online smoking cessation information failed to meet the USDHHS's recommendation regarding the reading level of health-related material. Government and voluntary health organizations hold themselves, and others, to a high standard of adhering to evidence-based practices. Thus, it is disconcerting that these organizations' websites do not meet the recommended reading level. It is important that these organizations model appropriate practices for Health Educators and smoking cessation specialists when creating these types of cessation materials, especially from the national government. It is ironic that the USDHHS provides Health Educators with resources to assist in creating easy-to-read health materials, ${ }^{31}$ yet several of their own materials analyzed in this study had high reading levels and were not statistically significant in terms of being different from the reading level scores of state health agencies and voluntary health organizations.

Unfortunately, the current study demonstrates that there has been minimal, if any, change in the reading level of cessation information provided to smokers over the past few decades. Earlier studies from the 1980s highlighted the issue of readability for information provided to smokers. ${ }^{12,22}$ The current study's findings are similar to previous research outlining the high reading levels used in smoking information in both print and online cessation materials. ${ }^{12,19-25}$ This trend needs to change in order to maximize the future impact of health educations materials for smokers interested in cessation.

This study also suggests that the Plain Writing Act of 2010 may not be adhered to regarding federal health agencies' smoking cessation materials. On October 13, 2010, President Obama signed the Plain Writing Act of 2010 into law, which requires federal agencies to use "clear Government communication that the public can understand and use." 32 Granted, although the Act may not explicitly specify that materials be written at or below the sixth-grade reading level, our findings indicate that staff at federal health agencies need to revise smoking cessation materials to at least comply with recommendations from leading voices in the field of public health in order to make the materials easy to read. The Act was a breakthrough in the government realizing the need to create clear, understandable communication to American citizens. From a Health Education perspective, the Act should be viewed as model policy to state and voluntary health organizations regarding health communication.

In addition, the findings from this study reflect a broader issue regarding the reading level of Health Education materials from various health topics. A large body of research within other health-related topics suggests that the reading level of nearly all educational materials is too high. These include materials regarding a wide array of health issues. ${ }^{17,18,33,34}$ Health Educators need to realize and act upon the need for educational materials that are easy to read. 


\section{Limitations}

Several limitations need to be considered when interpreting the results from this study. First, it is important to note that reading level scores are not the sole factor involved with measuring ease of reading and comprehension. Other factors include clarity of information, formatting of the materials, cultural suitability of the content, and so on. ${ }^{14}$ Moreover, reading level scores are simply scores that do not take the reader into consideration. All written materials should be pretested to ensure that the target audience can comprehend the information. ${ }^{14}$ Thus, it is possible that websites with high reading level scores in this study are indeed comprehendible by the intended audience.

Second, grade-level scores are less precise than they appear. For example, due to the SMOG formula's standard error, reading scores are approximated within \pm 1.5 reading levels. ${ }^{26}$ Therefore, it is possible that websites scored at the eighth-grade reading level could actually be near the sixth-grade reading level. ${ }^{14}$

Third, the websites included in the study were from a convenience sample. The authors may have failed to include all possible smoking cessation websites provided by governmental and voluntary health organizations. As such, the findings from this study are not generalizable to all smoking cessation websites.

Fourth, given the procedures of the SMOG formula, it is possible that the reading level scores would vary if replicated. The authors sampled 30 sentences from large bodies of text. Previous research suggests that different components of smoking cessation materials may be written at varying reading levels. For example, Brunette and colleagues found noteworthy differences between the reading level scores of homepages and medication pages of smoking cessation websites. ${ }^{25}$ Consequently, it may be possible that the reading level of each website could vary depending on the sentences collected from the beginning, middle, and end of each website's text.

Finally, because the study's methods excluded common polysyllabic words (eg, Minnesota, Tennessee, cigarette, nicotine), the online smoking cessation material would have been even higher in reading levels. However, the authors believed that it was necessary to remove these words from the sample of sentences, because it was likely that smokers would be able to identify the state in which they reside and common terms regarding smoking.

\section{Translation to Health Education Practice}

The authors recommend that health professionals who are responsible of online smoking cessation materials should update their text to aim for the health literacy levels of the public and smokers alike. Due to the high popularity of Internet usage, including almost all ages and socioeconomic statuses, ${ }^{5,35}$ and because research shows that cessation websites can be effective in helping smokers to make quit attempts, ${ }^{6-9}$ one could safely assume that a simple reduction in the reading level of online smoking cessation information could have an even greater impact. The amount of time and energy required to update these materials would be a worthwhile investment to improve readability and health outcomes.

Creating Health Education materials that are easy to read is within accordance to the National Commission of Health Education Credentialing's Area of Responsibility VII.

Area VII tasks health educators with clearly communicating Health Education to others. Two subcompetencies (7.1.2, 7.1.3) within Area VII outline Health Educator skills of being able to identify the intended audience's literacy level and to tailor health messages for that audience. ${ }^{36}$ These are crucial subcompetencies for ensuring that health messages are communicated effectively to others. These reflect the need for smoking cessation materials to be easy to read for the intended audience.

There are several helpful resources that health professionals can use to reduce the number of polysyllable words in their online smoking cessation materials. For example, the Centers for Disease Control and Prevention provides several free, online materials that can guide health professionals to write in plain language that is easy to read, such as the "Everyday Words for Public Health Communication" guide or the "Plain Language Planner." 31 These documents act as a type of thesaurus for Health Educators to replace technical, polysyllable terms with words that are shorter and easier to read. Likewise, the National Institutes of Health's "Plain Language at NIH" website contains a free training module for Health Educators to learn how to write documents that are easy to read. ${ }^{37}$

Finally, the authors suggest that state and voluntary health organizations implement policies similar to that of the Plain Writing Act of 2010. ${ }^{32}$ Although the Act is a law for federal agencies, state and voluntary health organizations could implement similar policies internally. Such policies would require Health Education materials to be written at lower reading levels and be vetted before being published. The authors recommend that such policies specify that the reading levels be at or below the sixth grade to reflect the recommendations of the USDHHS and others. 


\section{References}

1. Centers for Disease Control and Prevention. Current cigarette smoking among adults-United States, 2005-2015. MMWR Morb Mortal Wkly Rep. 2016;65:1205-1211.

2. U.S. Department of Health and Human Services. The Health Consequences of Smoking-50 Years of Progress: A Report of the Surgeon General. Atlanta, GA: U.S. Department of Health and Human Services, Centers for Disease Control and Prevention, National Center for Chronic Disease Prevention and Health Promotion, Office on Smoking and Health; 2014.

3. Centers for Disease Control and Prevention. Increases in quitline calls and smoking cessation website visitors during a national tobacco education campaign-March 19-June 10, 2012. MMWR Morb Mortal Wkly Rep. 2012;61:667-670.

4. Centers for Disease Control and Prevention. Best Practices for Comprehensive Tobacco Control Programs -2014. Atlanta, GA: U.S. Department of Health and Human Services, Centers for Disease Control and Prevention, National Center for Chronic Disease Prevention and Health Promotion, Office on Smoking and Health; 2014.

5. Fox S. Pew Internet \& American Life Project. Health Information Online. http://www.pewinternet.org/files/ old-media/Files/Reports/2005/PIP_Healthtopics_ May05.pdf.pdf. Published February 13, 2014. Accessed February 14, 2017.

6. An L, Schillo B, Saul J, et al. Utilization of smoking cessation informational, interactive, and online community resources as predictors of abstinence: cohort study. J Med Internet Res. 2008;10:1-12.

7. Cobb NK, Graham AL, Bock BC, Papandonatos G, Abrams D. Initial evaluation of a real-world Internet smoking cessation system. Nicotine Tob Res. 2005;7:207-216.

8. Etter JF. A list of the most popular smoking cessation websites and a comparison of their quality. Nicotine Tob Res. 2006;8:27-34.

9. Stoddard JL, Delucchi KL, Muñoz RF, et al. Smoking cessation research via the Internet: a feasibility study. $J$ Health Commun. 2005;10:27-41.

10. Cobb NK, Graham AL. Characterizing Internet searchers of smoking cessation information. J Med Internet Res. 2006;8:1-10.

11. National Center for Education Statistics. National Assessment of Adult Literacy: Demographics. http:// nces.ed.gov/naal/kf_demographics.asp. Published 2016. Accessed February 14, 2017.

12. Meade CD, Byrd JC. Patient literacy and the readability of smoking education literature. Am J Public Health. 1989;79:204-206.

13. Arnold CL, Davis TC, Berkel HJ, Jackson RH, Nandy I, London S. Smoking status, reading level, and knowledge of tobacco effects among low-income pregnant women. Prev Med. 2001;32:313-320.

14. U.S. Department of Health \& Human Services. Toolkit for making written material clear and effective. https:// www.cms.gov/Outreach-and-education/Outreach/
WrittenMaterialsToolkit/ToolkitPart07.html.

Published March 16, 2012. Accessed February 14, 2017.

15. Doak CC, Doak LG, Root JH. Teaching Patients With Low Literacy Skills. 2nd ed. Philadelphia, PA: J.B. Lippincott Company; 1996.

16. Weis B. Health Literacy: A Manual for Clinicians. Chicago, IL: American Medical Association, American Medical Foundation; 2003.

17. Walsh TM, Volsko TA. Readability assessment of Internet-based consumer health information. Respir Care. 2008;53:1310-1315.

18. Agarwal N, Hansberry DR, Sabourin V, Tomei KL, Prestigiacomo CJ. A comparative analysis of the quality of patient education materials from medical specialties. JAMA Intern Med. 2013;173:1257-1259.

19. Daley C, Cowan P, Nollen NL, Greiner KA, Choi WS. Assessing the scientific accuracy, readability, and cultural appropriateness of a culturally targeted smoking cessation program for American Indians. Health Promot Pract. 2009;10:386-393.

20. Gilbert P Readability and suitability of commonly used tobacco education materials. Paper presented at: 132nd Annual Meeting of the American Public Health Association Washington, DC; November 6-10, 2004. https://apha.confex.com/apha/132am/techprogram/ paper_79629.htm. Accessed February 14, 2017.

21. Gilbert H, Nazareth I, Sutton S. "Some of these words I can't pronounce": a qualitative exploration of the readability of generic and tailored self-help material for quitting smoking. J Appl Biobehav Res. 2009;14:1-14.

22. Meade CD, Byrd JC, Lee M. Improving patient comprehension of literature on smoking. Am J Public Health. 1989;79:1411-1412.

23. Cheh JA, Ribisl KM, Wildemuth BM. An assessment of the quality and usability of smoking cessation information on the Internet. Health Promot Pract. 2003;4:278-287.

24. Bock B, Graham A, Sciamanna C, et al. Smoking cessation treatment on the Internet: content, quality, and usability. Nicotine Tob Res. 2004;6:207-219.

25. Brunette MF, Ferron JC, Devitt T, et al. Do smoking cessation websites meet the needs of smokers with severe mental illnesses? Health Educ Res. 2012;27:183-190.

26. McLaughlin GH. SMOG grading-a new readability formula. Journal of Reading. 1969;12:639-646.

27. U.S. Department of Health and Human Services. Simply Put: A Guide for Creating Easy-to-Understand Materials. 3rd ed. Atlanta, GA: U.S. Department of Health and Human Services, Centers for Disease Control and Prevention, Strategic and Proactive Communication Branch, Division of Communication Services, Office of the Associate Director for Communication; 2010.

28. Friedman DB, Hoffman-Goetz L. A systematic review of readability and comprehension instruments used for print and web-based cancer information. Health Educ Behav. 2006;33:352-373.

29. U.S. Department of Health \& Human Services. Making Health Communication Programs Work: A Planner's Guide. Bethesda, MD: U.S. Department of Health \& Human Services, Public Health Service, National 
Institutes of Health, National Cancer Institute; 2004. Report No. T068.

30. Hedman AS. Using the SMOG formula to revise a health-related document. Am J Health Educ. 2008;39:61-64.

31. Centers for Disease Control and Prevention. Plain Language Materials \& Resources. https://www.cdc. gov/healthliteracy/developmaterials/plainlanguage. html. Published December 19, 2016. Accessed February 14, 2017.

32. Plain Language Action and Information Network. Plain Language: It's the Law. http://www.plainlan guage.gov/plLaw/index.cfm. Published May 2011. Accessed May 24, 2017.

33. Carbone ET, Zoellner JM. Nutrition and health literacy: a systematic review to inform nutrition research and practice. J Acad Nutr Diet. 2012;112:254-265.
34. Corcoran N, Ahmad F. The readability and suitability of sexual health promotion leaflets. Patient Educ Couns. 2016;99:284-286.

35. Perrin A, Duggan M, and Pew Research Center. Americans' Internet Access: 2000-2015. http://www. pewinternet.org/files/2015/06/2015-06-26_internetusage-across-demographics-discover_FINAL.pdf.

Published June 26, 2015. Accessed February 14, 2017.

36. National Commission of Health Education Credentialing. Responsibilities and Competencies for Health Education Specialists. https://www.nchec.org/responsibilities-andcompetencies. Published 2010. Accessed May 24, 2017.

37. National Institutes of Health. Plain Language at NIH. https://www.nih.gov/institutes-nih/nih-office-director/ office-communications-public-liaison/clear-communi cation/plain-language. Published 2011. Accessed May 24, 2017. 